\title{
Editoria
}

\section{Coming full circle: from European Tax Review to EC Tax Review}

Fred C. de Hosson, Caron \& Stevens/Baker \& McKenzie, Amsterdam

It was some four years ago that I took over from Professor Rädler the chief editorship of Intertax. On that occasion, I also decided to change Intertax's subtitle, 'European Tax Review', to 'International Tax Review'. I believed that there were good reasons for such a change. The major reason was undoubtedly that the title 'European Tax Review' was misleading in that, four years ago, there were no 'European taxes' or national taxes based on European rules, except in the field of indirect taxation. There were, of course, tax developments within the EEC Member States, but in view of the fact that there was no common background other than a geographical one, a limitation of the scope of the journal to EEC countries or European countries would not have been justified. Furthermore, four years ago, there were no indications that European taxes would come into being. Although it is true that, in 1986, the Commission clearly indicated within the framework of the Single European Act that the harmonization of direct taxes was to be an important component of its plan, the Member States continued to reserve their veto rights with respect to tax harmonization.

The fact that there was such a difficulty in adopting the two major draft Directives which had been initially proposed in 1969-the Parent-Subsidiary Directive and the Merger Directive - indicated an unwillingness on behalf of the Member States to surrender their sovereignty over matters of taxation.

The adoption of both Directives and an arbitration convention in the summer of 1990 was a total surprise. There can be no doubt that a significant part of the credit for this positive development is due to Mrs. Scrivener of the European Commission, who abandoned the ambitious and far-reaching harmonization attempts of the past and advocated a realistic approach on a step-by-step basis.

It appears that the Member States will continue on this path, albeit in a cautious manner. Two new Directives have been proposed and, in January 1992, the Ruding Commission will issue its report on the harmonization of corporate income tax. It is generally expected that the report will form the basis for the Commission's policy in the next decade.

The emergence of a real European tax law has led to a tremendous interest by the tax community in this field of law. The Intertax readers need only to browse the issues of this year to realize that the coming years will see a flow of publications.

In consultation with the publishers, it seemed a good idea to pay more attention on a systematic basis to the development of European taxation law by means of a separate Intertax supplement entitled 'EC Tax Review'. The supplement, to be issued each quarter, will contain in-depth background articles, as well as an extensive outline of legislative developments, courts' decisions and literature. The editorial staff, under the chairmanship of Professor Vanistendael, a member of the Ruding Commission, hopes that the EC Tax Review will establish a leading role in this extremely important field of law.

This does not mean that Intertax will leave this field of law entirely to the supplement. Intertax, being a monthly publication, can follow the current legal developments much more closely than a quarterly. The journal will therefore continue its column 'EC Tax Scene' and gladly accept articles which explain or comment on recent developments. 